\title{
Orbital apex syndrome with frontal abscess secondary to sinusitis due to Candida guilliermondii
}

Muhd-Syafi Abd Bari ${ }^{1,2,3}$, Mas Edi ${ }^{1,2}$, Hudzaifah Nordin ${ }^{1,2,6}$ Rosdan Salim ${ }^{2,4}$, Zamzuri Idris $^{2,5}$, Wan Hazabbah Wan Hitam ${ }^{1,2}$, Shatriah Ismail ${ }^{1,2}$

${ }^{1}$ Department of Ophthalmology and Visual Science, School of Medical Sciences, Universiti Sains Malaysia, Kubang Kerian, Kelantan, Malaysia; ${ }^{2}$ Hospital Universiti Sains Malaysia, Kubang Kerian, Kelantan, Malaysia; ${ }^{3}$ Department of Ophthalmology, Kulliyyah of Medicine, International Islamic University Malaysia, Kuantan, Pahang, Malaysia; ${ }^{4}$ Department of Otorhinolaryngology, School of Medical Sciences, Health Campus, Universiti Sains Malaysia, Kubang Kerian, Kelantan, Malaysia: ${ }^{5}$ Department of Neurosciences, School of Medical Sciences, Health Campus, Universiti Sains Malaysia, Kubang Kerian, Kelantan, Malaysia; ${ }^{6}$ Faculty of Medicine, Universiti Sultan Zainal Abidin Kampus Perubatan, Jalan Sultan Mahmud, Kuala Terengganu, Terengganu, Malaysia

\section{Abstract}

Candida guilliermondii is an opportunistic pathogen that rarely causes invasive candidiasis even in immunocompromised humans. We report a case presentation of invasive $C$. guilliermondii rhinosinusitis causing an orbital and intracranial extension (frontal lobe abscess). An aggressive multidisciplinary team management is a key approach in invasive fungal sinusitis and avoided mortality in this case. When orbital apex syndrome secondary to sinusitis is encountered in an immunocompromised patient, the treating physician should consider fungal infection as a causative agent.

Keywords: Candida guilliermondii, fungal rhinosinusitis, orbital apex syndrome

Correspondence: Dr. Muhd Syafi Abd Bari, Department of Ophthalmology and Visual Science, School of Medical Sciences, Universiti Sains Malaysia, 16150 Kubang Kerian, Kelantan, Malaysia.

E-mail: syafibari@iium.edu.my 


\section{Abstrak}

Candida guilliermondii adalah patogen oportunistik yang jarang menyebabkan penyakit kandidiasis invasif meskipun kepada manusia yang mengalami gangguan imun. Kami melaporkan kes kandidiasis invasif oleh C. guilliermondii rhinosinusitis yang menyebabkan penyebaran lanjutan ke orbit dan intrakranial. Penglibatan pelbagai disiplin medikal yang agresif adalah pendekatan utama dalam mengatasi masalah ini dan mengelakkan kematian. Apabila sinusitis yang menyebabkan sindrom orbital apeks ini dijumpai pada pesakit yang mempunyai gangguan sistem imun, doktor yang merawat perlu mempertimbangkan fungus ini sebagai salah satu punca jangkitan.

Kata kunci: Candida guilliermondii, fungus rinosinusitis, sindrom orbital apeks

\section{Introduction}

Fungal infection is one of the reported aetiologies of orbital apex syndrome, mainly as a sequela of rhinosinusitis. ${ }^{1}$ Fungal rhinosinusitis can be further classified into invasive and non-invasive. Immunocompromised patients, such as those with diabetes mellitus, cancer, leukaemia or acquired immune deficiency syndrome, are more commonly susceptible to this condition. ${ }^{2,3}$

\section{Case presentation}

A 54-year-old Malay female who had poorly controlled diabetes mellitus presented with progressive blurring of vision in the left eye for 3 weeks. It was associated with drooping of the left eyelid and proptosis, headache, facial numbness, and anosmia (Fig. 1).

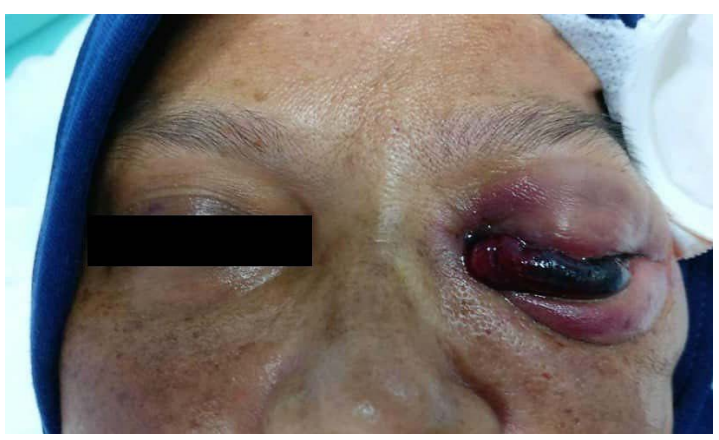

Fig. 1. Left eye swelling with proptosis, complete ptosis, and ophthalmoplegia. 


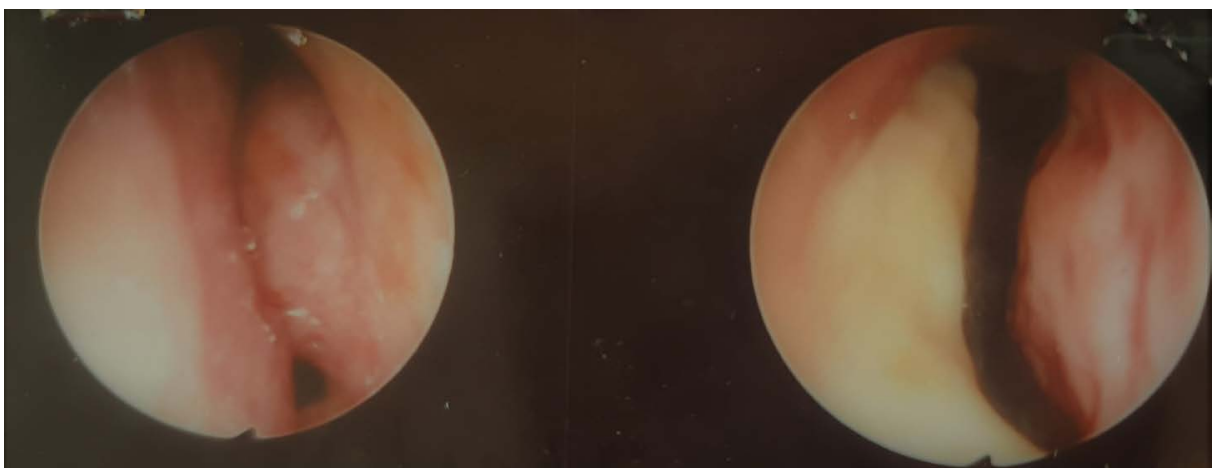

Fig. 2. (Left) Left oedematous and enlarged inferior turbinate. (Right) Thick crust and slough adhering to the septum.

On examination of the left eye, visual acuity was light perception with positive reverse afferent pupillary defect. Further examination revealed restricted gaze movement in all directions, complete ptosis, and marked proptosis. The anterior segment showed an injected conjunctiva with raised intraocular pressure. Fundoscopy showed pale disc with quiescent lasered proliferative diabetic retinopathy. On examination of the right eye, visual acuity was $6 / 18$ while the anterior segment was unremarkable. Fundoscopy examination showed moderate non-proliferative diabetic retinopathy.

The otorhinolaryngology team was referred to evaluate the involvement of the paranasal sinuses. Endoscopic examination revealed purulent lesions in both nasal cavities extending to the nasopharynx region (Fig. 2). A biopsy was taken from the lesions. Computed tomography scans of the brain, orbit, and paranasal sinuses showed extensive sinusitis involving the orbital apex region (Fig. 3) and extending into the intracranial space, causing left frontal abscess (Fig. 4). The histopathology result revealed fungal infection of $C$. guilliermondii. The patient underwent functional endoscopic sinus surgery and drainage of the frontal lobe abscess was performed by the neurosurgical team.

Intravenous amphotericin B $1 \mathrm{mg} / \mathrm{kg} /$ day was initiated. However, renal function was impaired, leading to drug-induced nephropathy. Intravenous medication was then switched to liposomal amphotericin B $3 \mathrm{mg} / \mathrm{kg} /$ day followed by oral voriconazole $200 \mathrm{mg}$ BD for 6 weeks. The patient's condition improved and a second computed tomography scan showed a reduction in lesion size.

However, the left eye progressed to neovascular glaucoma as a result of ischemia caused by the compressive effect of proptosis. During post-treatment follow-up, the vision progressed to no light perception and was treated conservatively with a single intraocular pressure-lowering agent. 


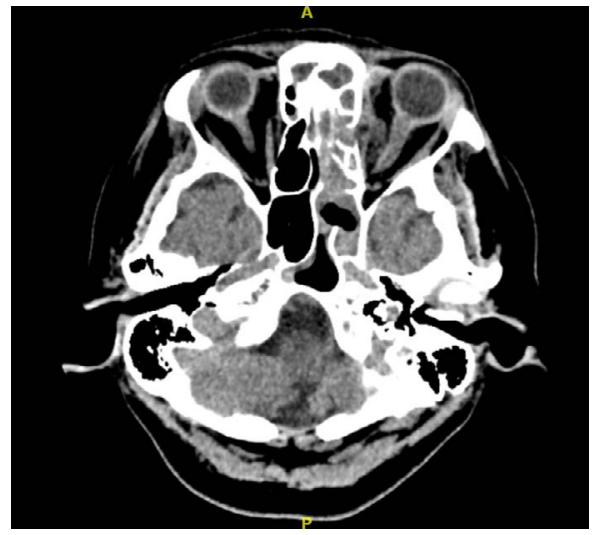

Fig. 3. Computed tomography of the orbit and paranasal sinuses showing mixed density lesion in left nasal cavity and ethmoid sinus, with extension to lateral extraconal space of left orbit. Left optic nerve was displaced and appear thickened.

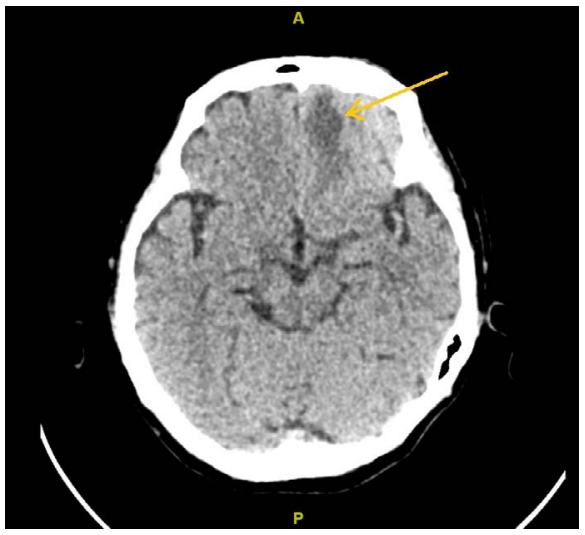

Fig. 4. Superior extension into the left frontal lobe area and ill-defined hypodensity posterior to left frontal abscess.

\section{Discussion}

Our case report exhibits a rare case of extensive rhinosinusitis caused by $C$. guilliermondii infection. It caused an invasive fungal sinusitis, extending intraorbitally causing orbital apex syndrome and intracranially causing left frontal lobe abscess.

C. guilliermondii is considered an uncommon yeast compared to Candida albicans. Reported cases of $C$. guilliermondii ocular infection caused chorioretinitis ${ }^{4}$ and fungal interstitial keratitis in post-Descemet's membrane endothelial keratoplasty. ${ }^{5}$ However, a case of $C$. guilliermondii causing an invasive rhinosinusitis with orbital and intracranial extension has never been reported in the literature before.

Invasive fungal sinusitis is a potentially fatal disease. The prognosis in this condition is usually poor because the orbital apex is located adjacent to the middle cranial fossa via the optic nerve canal and the superior orbital fissure. As such, a multidisciplinary approach is key to successful management.

Aggressive medical and surgical treatment is therefore necessary to reduce the mortality rate. ${ }^{2,6}$ Amphotericin B is a standard antifungal treatment for invasive fungal sinusitis due to its wide spectrum and high effectiveness; however, this medication occasionally impairs renal function. ${ }^{6}$ Therefore, a substitute of liposomal amphotericin B can be used in this condition. ${ }^{7}$

In our case, despite the success in treating the invasive $C$. guilliermondii infection and preventing a mortal outcome for our patient, the left eye progressed to neovascular glaucoma due to retinal ischemia secondary to the compressive effect 
of proptosis. Neovascular glaucoma is a devastating secondary glaucoma requiring early diagnosis, followed by immediate and aggressive treatment.

\section{Conclusion}

C. guilliermondii is an opportunistic pathogen and rarely causes invasive fungal sinusitis. When extensive orbital involvement in a rhinosinusitis case is encountered, the treating ophthalmologist should consider fungal infection as a causative agent.

\section{Declarations}

\section{Ethics approval and informed consent}

Not required.

\section{Consent for publication}

Consent was obtained from the patient for the publication of images and other clinical information reported in the journal.

\section{Competing interests}

None.

\section{Funding}

None.

\section{Acknowledgements}

The authors wish to thank the staff directly or indirectly involved in this study.

\section{References}

1. Lim CC, Liao IC, Lee WA. Orbital apex syndrome secondary to fungal sinusitis. QJM. 2020 Mar 1;113(3):205-206.

2. Deutsch PG, Whittaker J, Prasad S. Invasive and non-invasive fungal rhinosinusitis-a review and update of the evidence. Medicina. 2019;55(7):319.

3. Ahangarkani F, Badali $\mathrm{H}$, Rezai MS, et al. Candidemia due to Candida guilliermondii in an immuno-compromised infant: a case report and review of literature. Curr Med Mycol. 2019;5(1):32-36.

4. Tamura A, Kawamoto D, Minami K, et al. Candida guilliermondii-induced chorioretinitis in a patient with eating disorder. J Infect Chemother. 2021;27(4):642-646.

5. Augustin VA, Weller JM, Kruse FE, Tourtas T. Fungal interface keratitis after Descemet membrane endothelial keratoplasty. Cornea. 2018;37(11):1366-1369. 
6. Craig JR. Updates in management of acute invasive fungal rhinosinusitis. Curr Opin Otolaryngol Head Neck Surg. 2019;27(1):29-36.

7. Kang H, Takahashi Y, Nishimura K, Yamagishi Y, Mikamo H, Kakizaki H. Invasive Fungal Sinusitis Involving the Orbital Apex in a Patient with Chronic Renal Failure. Neuro-Ophthalmology. 2015;39(4):183186. 